最後に，文旦果皮のメタノール漫出液を濃縮して得られるナリンギンの結晶塊を水可再結晶する

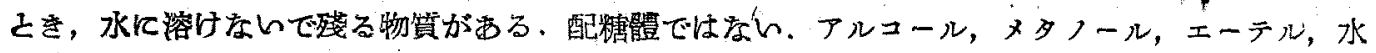

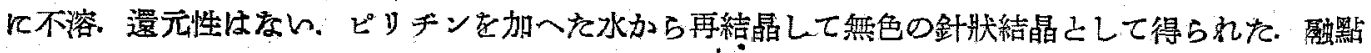

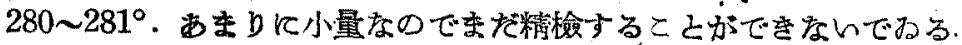

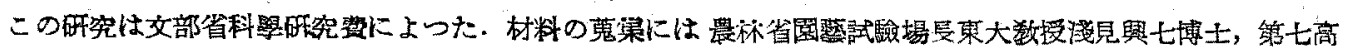

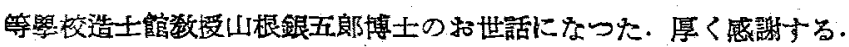

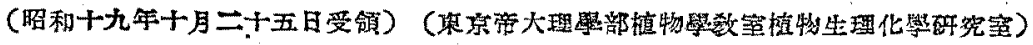

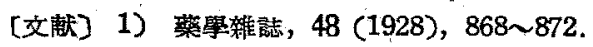

2) 本誌, 65 (1944), 744 .

$$
\text { (? }
$$

\title{
氣體電子廻折法に上る分子榡造の研究（第一, 二報）
}

森野米三木村”雅男 長谷川美知男

\section{（第一報）四監化炭素及びクロロフォルムの分子構造}

氣體專用の電子線カメラを製作し1), 先づ四監化炭素につんて珼驗を行ひ, 結果を Pauling, Brockway の揤定值 ${ }^{2}$ ，比較して十分使用し得るととを確めた.（カメラの焦點距離は約 $11 \mathrm{~cm}$, 電子線め波長恃約 $0.07 \AA$ ). 次いでクロロフォルムに就いて管 驗して第 1、表の如委 11 個の迴折環を得た。

筫測值より分子構造を 決定するには Pauling の方法に從つ て，迴折環の强度分布は

$$
I=k \sum_{i<j} Z_{i} Z_{3} \frac{\sin s l_{i j}}{s l_{l_{2}}}
$$

凡よつて表はされるすのよして，(但し $Z_{i}, Z_{j}$ は夫ょ $i, j$ 原子

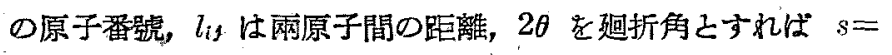
$4 \pi \sin \theta / \lambda$ ) その極大極小が管湘の場所に最る良く合尔稼に $l_{l}$ を決定した。，その結果汁次の通りでする。

四壏化炭素 $\mathrm{CCl}_{4}: \mathrm{C}-\mathrm{C}=1.77 \AA( \pm 0.01 \AA)$, 正四面體構造 クロロフォルム $\mathrm{CHCl}_{3}: \mathrm{C}-\mathrm{H}=1.09 \AA$ (假定)

$$
\begin{aligned}
& \mathrm{C}-\mathrm{Cl}=1.77 \AA( \pm 0.01 \AA) \\
& <\mathrm{Cl}-\mathrm{C}-\mathrm{Cl}=112^{\circ}\left( \pm 1^{\circ}\right)
\end{aligned}
$$

第 1 表 クロロフォルムの

迴折環门實㨽值

\begin{tabular}{c|r|r}
\hline \hline 極大 & $s$ (本桼驗) & $s$ (Pauling) \\
\hline 1 & 2.90 & 2.74 \\
2 & 4.84 & 4.78 \\
3 & 7.11 & 6.99 \\
4 & 9.08 & 9.04 \\
5 & 11.18 & 11.16 \\
6 & 13.39 & 13.32 \\
7 & 15.49 & 15.32 \\
8 & 17.69 & 17.47 \\
9 & 19.63 & \\
10 & 22.00 & \\
11 & 24.03 & \\
\hline
\end{tabular}

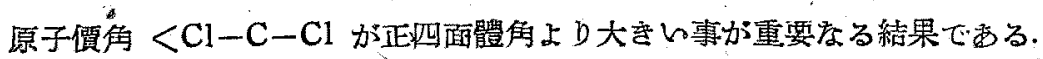

次に多口フォルムの分子內和テンシャルエネルギーとして次の式老假定する.

$V=\frac{3}{2} f_{2}{\overline{r_{0} \delta \theta}}^{2}+\frac{3}{2} f_{2}{\overline{r_{0} \delta \alpha}}^{2}+\frac{3}{2} h_{q}^{\mathrm{ClCl}} q_{0}{ }^{\mathrm{ClCl}} \delta q^{\mathrm{ClCl}}+\frac{3}{2} f_{q}^{\mathrm{ClCl}}{\overline{\delta q^{\mathrm{ClCl}}}}^{2}+\frac{3}{2} h_{\mathrm{q}}^{\mathrm{HCl}} q_{0}{ }^{\mathrm{HCl}} \delta q^{\mathrm{HCl}}+\frac{3}{2} f_{\mathrm{q}}^{\mathrm{HCl}}{\overline{\delta q^{\mathrm{HCl}}}}^{2}$

第 1，第 2 項は夫ぬ $<\mathrm{Cl}-\mathrm{C}-\mathrm{Cl}$ 及び $<\mathrm{H}-\mathrm{C}-\mathrm{Cl}$ の正四面體角よりの偏差によるポテンシャ

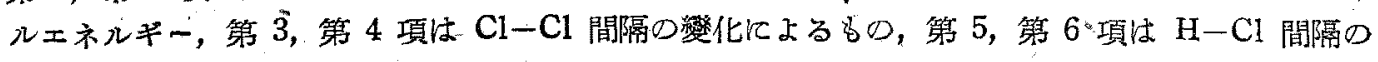


委化によるすのを表はす．結合原子間隔は一定之假定した．而して力の恒數として四監化炭素のラ

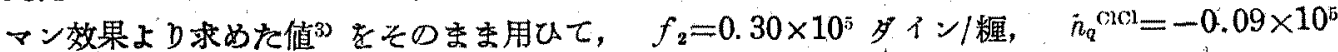

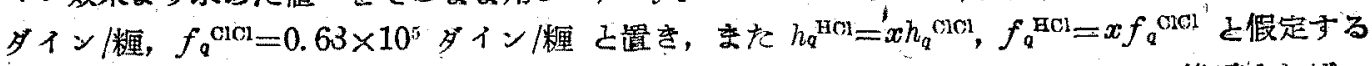

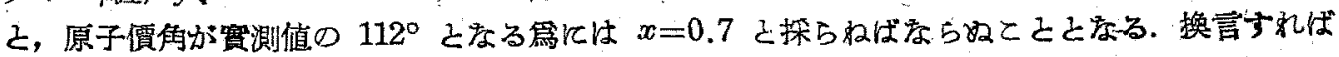

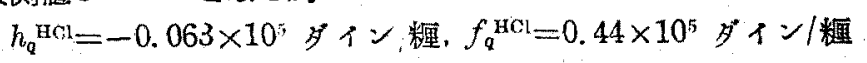

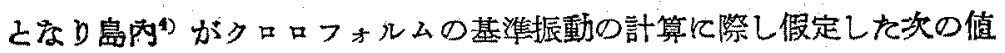

$$
\begin{aligned}
& h_{\mathrm{q}}^{\mathrm{BCl}}=\frac{h_{\mathrm{q}}^{\mathrm{HH}}+h_{\mathrm{q}}^{\mathrm{CICl}}}{2}=-0.0483 \times 10^{5} \text { ダイン/緾 } \\
& f_{Q}^{\mathrm{HCl}}=\frac{f_{q}^{\mathrm{HH}}+f_{q}^{\mathrm{GC}}}{2}=0.367 \times 10^{5} \text { ダイン/惰 }
\end{aligned}
$$

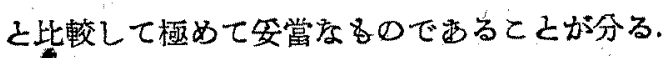

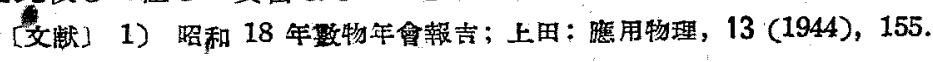

2) Pauling, Brockwy: J. Chem. Phys., 2 (1934), 867.

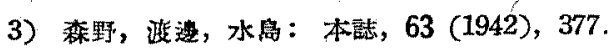

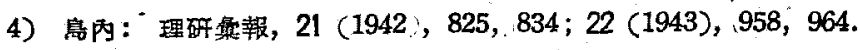

\section{（第二報）フロモフォルムの分子構造}

第一報に引續きブロモフォルムの電子線迴折寫真を撮影して第 1 表に示寸迴折摆 12 個を得を. 而して第一報さ同樣に解析した結果次の分于楧造を得を.

$$
\begin{aligned}
& \mathrm{C}-\mathrm{H}=1.09 \AA(\text { 假定 }) \\
& \mathrm{C}-\mathrm{Br}=1.90 \AA( \pm 0.01 \AA) \\
& \mathrm{Br}-\mathrm{Br}=3.18 \AA( \pm 0.01 \AA) \\
& <\mathrm{Br}-\mathrm{C}-\mathrm{Br}=113.5^{\circ}\left( \pm 1^{\circ}\right)
\end{aligned}
$$

此處江注目すべき點はクロロフォルム上同樣に $<\mathrm{Br}-\mathrm{C}-\mathrm{Br}$

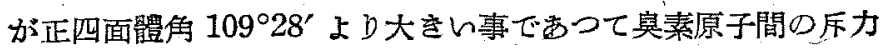
による8の之思机る。

さてクロロフォルムの場合之同碌分子内甫テンシャルエネ ルギーこして原子價角が正四面體角をなす時よりの偏差を以て 次の如く表はし得る西の上假定する.

$$
\begin{aligned}
& V=\frac{3}{2} f_{2}{\overline{r_{0}}}^{2} \theta^{2}+\frac{3}{2} f_{2}{\overline{r_{0} \delta \alpha}}^{2}+\frac{3}{2} h_{q}^{\mathrm{BrBr}} q_{0}^{\mathrm{BrBr}} \delta q^{\mathrm{BrBr}}
\end{aligned}
$$

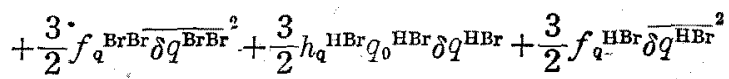

第 1 表 プロモフォルム 趈折環の凟測值

\begin{tabular}{c|c|c|}
\hline \hline 極大 & $s$ (本羷) & $s($ Levy $)$ \\
\hline 1 & 2.56 & 2.693 \\
2 & 4.58 & 4.480 \\
3 & 6.65 & 6.519 \\
4 & 8.64 & 8.459 \\
5 & 10.56 & 10.48 \\
6 & 12.57 & 12.45 \\
7 & 14.51 & 14.41 \\
8 & 16.46 & 16.45 \\
9 & 18.38 & 18.32 \\
10 & 20.16 & 20.34 \\
11 & 22.13 & 22.36 \\
12 & 23.96 & \\
\hline
\end{tabular}

力の恒数として液體四臭化炭素のシマン效果の結果を用ひた島內2 の計算により， $f_{2}=0.0452 \times$ $10^{5}$ ダイン/粴, $h_{\mathrm{q}}^{\mathrm{BrBr}}=-0.0778 \times 10^{5}$ ，ダイン/粧， $f_{\mathrm{q}}^{\mathrm{BrBr}}=0.493 \times 10^{5}$ ダイン/榞を使用し，更に

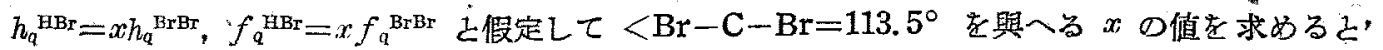

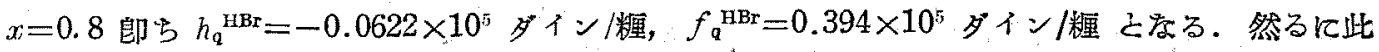

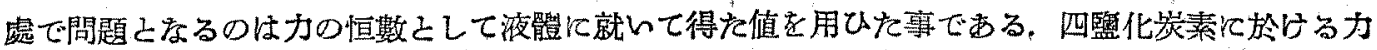
の恒數は液體のラマン效果より求めを值と氣體のラマン效果より求めた值とを比较するこ，他の恒

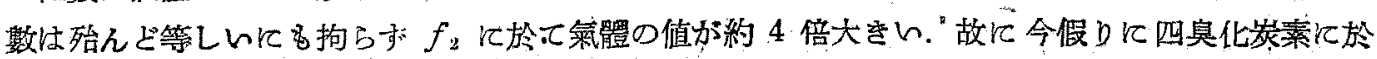

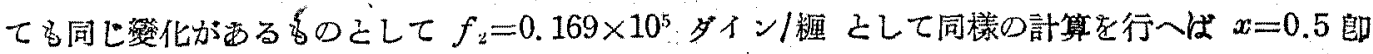




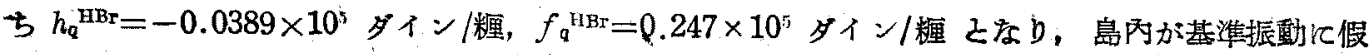
定しな佂?

$$
\begin{aligned}
& h_{q}^{\mathrm{HBr}}=\frac{h_{q}^{\mathrm{HH}}+h_{\mathrm{q}}^{\mathrm{BrBr}}}{2}=-0.0389 \times 10^{5} \text { タイン/糎 } \\
& f_{q}^{\mathrm{HBr}}=\frac{f_{q}{ }_{\mathrm{HH}}+f_{\mathrm{q}}^{\mathrm{BrBr}}}{2}=0.285 \times 10^{5} \text { ダイン/輝 }
\end{aligned}
$$

と比端すれ代補正した力の゙恒斯を使用した場合の方が良を一致を示すことを知る。勿論決定的な結

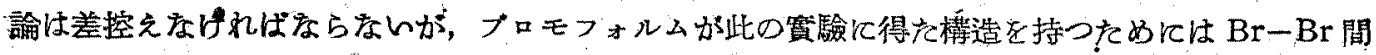

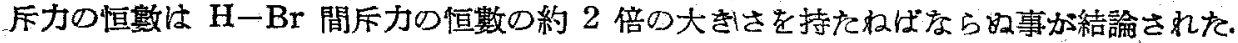

[交嗝] 1) Levy, Brockway: J. Am. Chem. Soc., 59 (1937), 1662.

2) 島丙：理研农郝, 21 (1942), 834.

（昭和十九年十一月十八日受領）（名古屋帝國大學理學部）

\section{本邦西部の溫泉の地球化學的研究（第十一報）}

\section{鳥取縣の溫泉のラドン含有量}

松浦新之助田多千賀夫麻生嘻見

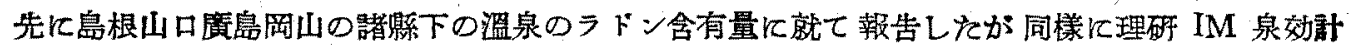
を用ひて鳥取縣下の温泉のラドン含有量を測定した。その結果は第 1 表の通りでめる.

\begin{tabular}{|c|c|c|c|c|c|c|c|}
\hline \multirow[t]{2}{*}{ 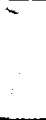 } & \multirow{2}{*}{ 温泉名 } & \multirow{2}{*}{${ }^{\text {泉 }{ }^{\circ} \mathrm{C}}$} & \multirow{2}{*}{$\mathrm{pH}$} & \multicolumn{2}{|c|}{ フドン含有量 } & \multirow{2}{*}{$\begin{array}{c}\text { 荎弡殘涬 } \\
\mathrm{g} / \mathrm{l}\end{array}$} & \multirow{2}{*}{$\begin{array}{c}\text { 测定期日 } \\
\text { 昭和一年一月一日 }\end{array}$} \\
\hline & & & & $\begin{array}{c}10-10 \\
+2 y-12\end{array}$ & マッへ & & \\
\hline I & 岩井温泉 & & & & & & \\
\hline & 岩井屋の晹 & 49.7 & 5.6 & 4.12 & 1. 13 & - & 18 $12-7$ \\
\hline & 元 & 49.0 & 5.6 & 2.15 & 0. 59 & - & $"$ \\
\hline II & ，吉岡温泉 & & & & & & \\
\hline & 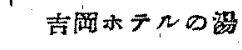 & 49.8 & 6.8 & 9.70 & 2.67 & - & $18-12-9$ \\
\hline & 株 & 54.8 . & 6.9 & 7.54 & 2.07 & 0.4960 & $" \prime$ \\
\hline & 中 $\varnothing$ 㳻 & 51.9 & 6.6 & 14.52 & 3.99 & - & $18-12 \cdot 8$ \\
\hline & 中島屋口酒 & 50.0 & 6.6 & 19.49 & 5.36 & - & " \\
\hline III & 窗村跨見温家 & & & & & & \\
\hline & 鉿未屋の晹 & 50.5 & 5.6 & 15.77 & 4.34 & 1. 1265 & $18 \cdot 12-7$ \\
\hline & 木下，の晹 & 64.6 & 6.0 & $20.90^{\circ}$ & 5.75 & 1.3285 & 18126 \\
\hline & 鉿木（垌）の湿 & 60.5 & 5.9 & 13.20 & 3.63 & 1.3465 & $" \prime$ \\
\hline & 鉿木 (隆) 口湯 & 70.0 & 6.0 & 68.69 & 18.89 & 1.3255 & $"{ }^{\prime}$ \\
\hline & 中田 0 湯 & 46.1 & 5.8 & 35.5 & 9.76 & 0.9160 & $18 \cdot 12-7$ \\
\hline & 清 鉿 & 40.3 & 5.6 & 172.0 & 47.3 & 1.6340 & 18126 \\
\hline
\end{tabular}

第 1 表 